\title{
INVESTIGATION INTO THE INFLUENCE OF FLAME RETARDANT ADDITIVES ON SOME FIRE PROPERTIES OF POLYESTER MATERIALS APPLYING SMALL-SCALE TESTING TECHNIQUES
}

\author{
Marzena PÓŁKA ${ }^{\mathrm{a}}$, Jerzy GAŁAJ ${ }^{\mathrm{a}}$, Zbignev KARPOVIČ ${ }^{\mathrm{b}}$ \\ ${ }^{a}$ Department of Fire Safety Engineering, The Main School of Fire Service, Slowackiego str. 52/54, \\ 01-692, Warsaw, Poland \\ ${ }^{b}$ Department of Labour Safety and Fire Protection, Vilnius Gediminas Technical University, Sauletekio al. 11, \\ LT-10223, Vilnius, Lithuania
}

Received 28 Jan. 2013; accepted 4 Mar. 2013

\begin{abstract}
In order to investigate the impact of some inorganic additive flame retardants on the selected fire properties of the materials based on polyester resin Polimal 1033 APy, small-scale fire testing techniques have been used. Seven samples have been studied: unmodified PES, PES modified with $\mathrm{MoO}_{3}(7,14$ and $21 \mathrm{wt} \%)$ and PES modified with $\mathrm{Sb}_{2} \mathrm{O}_{3}(7,14$ and $21 \mathrm{wt} \%)$. The following flammable properties of materials have been determined: the heat of combustion (HOC), the ignition temperature of volatile thermal decomposition products $\left(\mathrm{T}_{\mathrm{ig}}\right)$, self-ignition temperature and oxygen index. A cone calorimeter method has been used for determining heat release rate (HRR), mass loss, specific extinction area (SEA) and other combustion parameters. The toxicological analysis of combustion products has been conducted. Based on the obtained results, the following conclusions have been made: (1) $\mathrm{MoO}_{3}$ and $\mathrm{Sb}_{2} \mathrm{O}_{3}$ added to the studied material change its flammable properties and fire parameters. It can be indicated by higher HOC, higher $\mathrm{T}_{\mathrm{ig}}$ and self-ignition temperature, as well as by lower HRR and SEA. Modified materials become safer in terms of fire hazard. (2) A significant reduction in $\mathrm{HRR}_{\max }$ of approx. $40 \%$ in the content of $7 \mathrm{wt} \%$ has been observed. The lowest $\mathrm{HRR}_{\max }$ of approximately $300 \mathrm{~kW} / \mathrm{m}^{2}$ and $450 \mathrm{~kW} / \mathrm{m}^{2}$ have been obtained for $21 \mathrm{wt} \%$ in a range of $200-600 \mathrm{~s}$ at $30 \mathrm{~kW} / \mathrm{m}^{2}$ and $100-400 \mathrm{~s}$ at $50 \mathrm{~kW} / \mathrm{m}^{2}$ respectively. Except for a sample containing $7 \mathrm{wt} \%$ of $\mathrm{Sb}_{2} \mathrm{O}_{3}$, a clear local reduction in HRR (from 50 to $150 \mathrm{~kW} / \mathrm{m}^{2}$ ), in case of all modified samples has been noticed. (3) $\mathrm{Sb}_{2} \mathrm{O}_{3}$ has a greater impact on the thermostability of the studied materials compared to $\mathrm{MoO}_{3}$ in all cases of heat flux density and additive concentrations. The effectiveness of $\mathrm{Sb}_{2} \mathrm{O}_{3}$, as a flame retardant is the most evident at $21 \mathrm{wt} \%$.

Keywords: polyester materials; flame retardants; Polimal 1033 APy; small-scale fire testing; thermogravimetric analysis; flammable properties; cone calorimeter method; toxicological analysis.

Reference to this paper should be made as follows: Półka, M.; Gałaj, J.; Karpovič, Z. 2013. Investigation into the influence of flame retardant additives on some fire properties of polyester materials applying small-scale testing techniques, Journal of Civil Engineering and Management 19(4): 561-572.

http://dx.doi.org/10.3846/13923730.2013.793610
\end{abstract}

\section{Introduction}

Polyester materials are of high significance among many types of materials applied nowadays in building engineering (building elements, division walls, glass roofs, structural elements, floor screeds). They are also used in textile industry, automotive industry, electronics, etc.

Traditional methods for reducing flammability are based on the modification of plastics by adding flame retardants, the so called antipyrenes, for example, as curing agents or fillers (Gałaj et al. 2012; Pofit Szczepańska, Półka 2002a, b, 2003; Półka 2001). Flame retardants inhibit the process of the thermal decomposition of the material subjected to thermal radiation resulting in a reduction in material combustion rate. A consequence of such process, among the others, is lower material flammability and a slower increase in fire temperature and $\mathrm{CO}$ concentration creating more favorable conditions for evacuation from the building. Basically, two mechanisms of acting antipyrenes, including physical and chemical, can be distinguished (Jankowska et al. 2007; Wilkie, Morgan 2009). The physical effect of the flame retardant agent mainly consists of the gas dilution phase and the formation of barrier layers that block the mass flow of thermal decomposition products and energy flow

Corresponding author: Jerzy Gałaj

E-mail: jgalaj@sgsp.edu.pl 
between gas and solid phases during material combustion. The chemical effect consists of antipyrene entering into free radical reactions of the combustion process in the gas phase and/or into reactions occurring in the solid phase.

A disadvantage of some flame retardants is frequently an increase in the toxicity degree of thermal decomposition products and the combustion of modified polymers in the fire environment. The products formed during combustion also pose danger to people during evacuation. Thus, due to the toxicity of the products of thermal decomposition and combustion, in recent years, the agents consisting of halogen atoms have been often substituted by halogen-free inhibitors.

A large number of papers present the analyzed results of different mechanisms for fire retardancy of polymer materials and small-scale fire tests using standard methods, such as a cone calorimeter, thermogravimetric analysis (TGA), limited oxygen index (LOI), a differential scanning calorimeter (DSC) and/ or a vertical burning test (UL 94) (Carosio et al. 2012; Fukushima et al. 2010; Kandare et al. 2008; Kiliaris, Papaspyrides 2010; Konecki, Półka 2006, 2009a, b; Laoutid et al. 2009; Li et al. 2012; Pan et al. 2012; Pereira et al. 2009; Półka 2001; Seetapan et al. 2011; Tang et al. 2012; Tibiletti et al. 2011; Wei et al. 2011). The main directions of research in the considered field of the study include the determination of susceptibility to initiate combustion reactions, particularly under thermal and flow conditions simulating the $1^{\text {st }}$ phase of fire, the quantitative and qualitative composition of thermal decomposition products reflecting smokegenerating capacity and the toxicity of the fire environment, the formation rate of critical heat flux during the combustion of epoxides enabling the transition of the 1 st fire phase into the $2^{\text {nd }}$ active phase, as well as the influence of the physical and chemical parameters of additives on the flammability of polyesters.

In order to investigate the behavior of polyester material based on Polimal 1033 Apy, the experimental part of the study on thermal and flammable properties looks at unmodified and modified inorganic additives during fire occurrence, as well as reveals heat release rates at the selected heat flux according to ISO 56601:2002 (Konecki, Półka 2005; Półka 2001). The toxicity of materials according to PN-88/B-02855 (1988) has been also investigated.

\section{Subject of the study}

For experimental small-scale studies by means of the cone calorimeter method, a trade name of polyester resin (PES) Polimal 1033 APy produced in the Chemical Plant Organika Sarzyna in Nowa Sarzyna, Poland and commonly applied in building engineering has been used. Structural resin has low viscosity and is medium elastic, orthophtalic and pre-accelerated. An abbreviation at the end of the name stands for ecological, low styrene emission (letter A) and accelerated resin and does not require the use of cobalt accelerator (symbol Py). The basic parameters of resin are provided in Półka (2001).

For modifying Polimal 1033 Apy resin, two inorganic oxides were used: antimony trioxide $\left(\mathrm{Sb}_{2} \mathrm{O}_{3}\right)$ and molybdenum trioxide $\left(\mathrm{MoO}_{3}\right)$. The size of the mesh $\mathrm{Sb}_{2} \mathrm{O}_{3}(\alpha)$ was up to $23 \mu \mathrm{m}$; however, $\mathrm{MoO}_{3}$ made of $2-10 \mu \mathrm{m}$ was produced by POCH S. A. Gliwice (Chemical Corporation in Poland). Modifications are aimed at enhancing fire resistance properties of resin. The quantities of added antipyrenes have been selected experimentally. Concentration range of additives depended on visible changes in a particular fire property of the lowest additive concentration and a lack of registered change in the same parameter of fire above the highest applied concentration of the additive. For selecting inorganic filler, a change in resin viscosity and gelation time was taken into account. The method of modification for both additives was the same. Both additives were added to polyester resin obtained as a result of polycondensation at a temperature of $t=25^{\circ} \mathrm{C}$ and pressure $p=0$ atm (Półka 2001).

For small-scale studies, pure PES polyester and polyesters modified adding flame retardants reducing their flammability were used. The content of the additives in the modified samples was $7 \mathrm{wt} \%, 14 \mathrm{wt} \%$ and $21 \mathrm{wt} \%$. Pure PES was transparent. The material with molybdenum addition was green, while a sample with the addition of antimony was white.

\section{Test stand and measuring methods}

The thermal analysis of unmodified and modified polyester materials was conducted in dynamic conditions. Thus, the mass of the studied decomposed sample was registered as a function of temperature at a constant heating rate. For thermogravimetric studies, the shredded samples of polyester material (of approx. $0.5 \mathrm{~mm}$ ) made of unmodified Polimal 1033 Apy and modified with inorganic oxides having the mass of 140-170 mg were used. Thermal analysis was performed applying a derivatograph manufactured by Hungarian company MOM - Budapest (Magyar Optikai Muvek). The samples were placed in a thermoanalyzer oven and tested in the temperature range of $20-1000{ }^{\circ} \mathrm{C}$ at three different heating rates $2.5,5$ and $10{ }^{\circ} \mathrm{C} / \mathrm{min}$. Analyses were conducted under atmospheric conditions.

In order to investigate the flammable properties of seven analyzed polyester materials, the following parameters were determined: combustion heat, the ignition temperature of volatile products of thermal decomposition, self-ignition temperature and oxygen indexes of the studied polyesters. The heats of combustion analysis were carried out based on PN81/G-04523 (1981). The chosen method consisted of the complete combustion of the weighed sample of a 
(a)

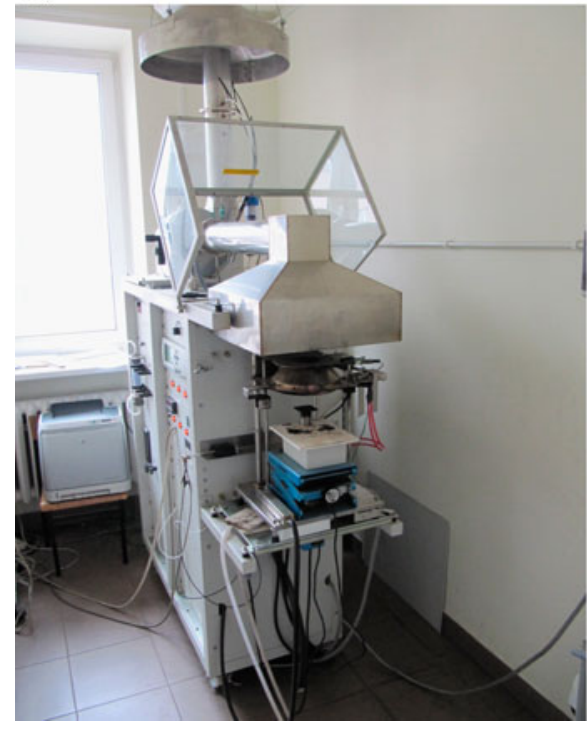

(b)

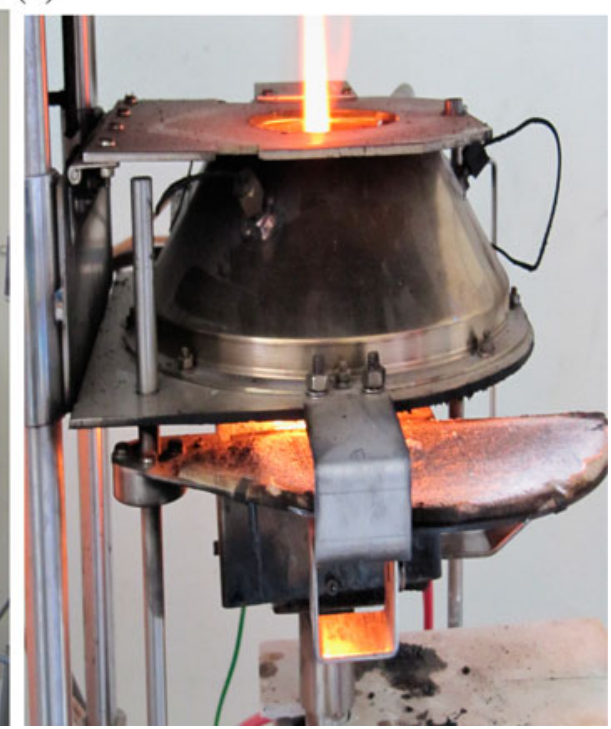

Fig. 1. General view of the cone calorimeter (a) and a burner with the sample after piloted ignition (b)

solid material in oxygen atmosphere under pressure in a bomb calorimeter and the measurement of temperature growth in water in the calorimetric vessel. For studying combustion heat, the samples of polyester products were used - shredded to the fraction of $1 \mathrm{~mm}$ of $1 \mathrm{~g}$ mass. The ignition temperature of the volatile products of thermal decomposition was determined according to PN-69/C-89022 (1969). The method consists of heating the sample up to temperature lower than $10{ }^{\circ} \mathrm{C}$ of the expected thermal decomposition temperature and testing the ignition (during $5 \mathrm{~min}$ ) of emitted pyrolytic gases with reference to an auxiliary ignition source (most frequently flame). Polyester material samples shredded to the fraction of $0.5 \mathrm{~mm}$ (mass $=1 \mathrm{~g}$ ) were placed in a metal thimble and put into an oven under constant temperature in the range of $150-400{ }^{\circ} \mathrm{C}$. Self-ignition temperatures of unmodified samples and samples modified with inorganic oxides were determined based on the method described in ASTM D 1929-77 (1977). The method consists of placing the sample in the oven with adjustable temperature and measuring the lowest temperature of the oven walls at which the selfignition of thermal decomposition products occur. This self-ignition temperature can be determined under both static and dynamic conditions. The dynamic method was applied (Stechkin apparatus CS- 88 by Custom Scientific Instruments) in the presented studies more accurately reflecting fire conditions. The studies focused on the air conditioned samples of polyester material having the dimensions of $20 \times 20 \mathrm{~mm}$ and the mass of $3 \pm 0.5 \mathrm{~g}$. The determination of oxygen indexes was conducted based on PN-76/C-89056 (1976) standard. The method of oxygen index consists of determining the lowest oxygen concentration in the oxygen and nitrogen mixture, at which a plastic sample fixed vertically in the measuring column burns for 3 minutes at a length of $5 \mathrm{~cm}$. The samples of polyester materials with a shape of rectangular beams and dimensions of $80 \times 1 \times$ $4 \mathrm{~mm}$ were tested employing standard test equipment manufactured by Stanton Redcroft.

For analyzing heat release rate and other combustion parameters, a cone calorimeter manufactured by Fire Testing Technology (Great Britain) was applied. Its general view is given in Fig. 1a. The tests were conducted according to ISO 5660-1:2002 standard. The samples of the studied polyester materials were subjected to the influence of the heat flux of $30 \mathrm{~kW} / \mathrm{m}^{2}$ and $50 \mathrm{~kW} / \mathrm{m}^{2}$. To select the power of heat radiation to determine fire parameters, a thermal flux simulating the 1st and 2nd phase of fire was used. Ignition was initiated by piloted ignition. The ignition of volatile products was performed by means of a spark igniter. The studies employed a horizontal placement of the tested samples with regards to the radiator (see Fig. 1b). Before testing, unmodified and modified polyester material samples having the dimensions of $100 \times 100 \mathrm{~mm}$ were stored at $20 \pm 2{ }^{\circ} \mathrm{C}$, wrapped in aluminum foil and placed in the test frame for cone calorimeter studies. A surface of the samples subjected to heat flux impact was $88.4 \mathrm{~cm}^{2}$, the thickness of the profiles was $4-5 \mathrm{~mm}$, and the initial weight of the samples varied by a small percentage.

\section{Studies on the results of thermal properties}

The results of the thermal properties of polyester material samples are given in Table 1. The thermal distribution of the studied materials is a function of their composition and heating rate. Unmodified polyester in the range of the studied temperature 
Table 1. Decomposition temperatures and mass loss of the studied polyester materials

\begin{tabular}{|c|c|c|c|c|}
\hline Material & $\begin{array}{l}\text { Heating rate } \\
\left({ }^{\circ} \mathrm{C} / \mathrm{min}\right)\end{array}$ & $\begin{array}{l}\text { Initial tempera-ture of } \\
\text { thermal decompo-sition }\left({ }^{\circ} \mathrm{C}\right)\end{array}$ & $\begin{array}{l}\text { Tempera-ture of maximum } \\
\text { mass loss }\left({ }^{\circ} \mathrm{C}\right)\end{array}$ & $\begin{array}{l}\text { Maxi-mum mass } \\
\text { loss }(\%)\end{array}$ \\
\hline \multirow[t]{3}{*}{ Clear PES } & 2.5 & 165 & 260 & 75 \\
\hline & 5 & 180 & 270 & 74 \\
\hline & 10 & 180 & 270 & 73 \\
\hline \multirow[t]{3}{*}{$\mathrm{PES}+7 \% \mathrm{MoO}_{3}$} & 2.5 & 185 & 290 & 69 \\
\hline & 5 & 182 & 290 & 67 \\
\hline & 10 & 182 & 291 & 66 \\
\hline \multirow[t]{3}{*}{$\mathrm{PES}+14 \% \mathrm{MoO}_{3}$} & 2.5 & 195 & 300 & 70 \\
\hline & 5 & 193 & 320 & 69 \\
\hline & 10 & 193 & 300 & 70 \\
\hline \multirow[t]{3}{*}{$\mathrm{PES}+21 \% \mathrm{MoO}_{3}$} & 2.5 & 192 & 300 & 46 \\
\hline & 5 & 195 & 302 & 50 \\
\hline & 10 & 195 & 312 & 51 \\
\hline \multirow[t]{3}{*}{$\mathrm{PES}+7 \% \mathrm{Sb}_{2} \mathrm{O}_{3}$} & 2.5 & 190 & 350 & 67 \\
\hline & 5 & 180 & 290 & 74 \\
\hline & 10 & 185 & 385 & 74 \\
\hline \multirow[t]{3}{*}{$\mathrm{PES}+14 \% \mathrm{Sb}_{2} \mathrm{O}_{3}$} & 2.5 & 180 & 340 & 62 \\
\hline & 5 & 200 & 350 & 76 \\
\hline & 10 & 210 & 380 & 69 \\
\hline \multirow{3}{*}{$\mathrm{PES}+21 \% \mathrm{Sb}_{2} \mathrm{O}_{3}$} & 2.5 & 180 & 270 & 63 \\
\hline & 5 & 200 & 360 & 58 \\
\hline & 10 & 210 & 370 & 59 \\
\hline
\end{tabular}

and at applied heating rates does not change its thermostability. The temperatures of starting thermal decomposition and maximum mass loss, influencing mainly the ignition temperatures of the studied materials vary slightly, which indicates that the variable heating rate of polyester material based on Polimal 1033 APy at the beginning of the $1^{\text {st }}$ phase of fire, does not influence the rate of forming the fire environment. Modification with flame retardants such as molybdenum or antimony oxides has an impact on the thermostability of the material. The results of thermogravimetric studies shown in Table 1 indicate an inhibitive impact of both applied oxides, while significant effect has heating rate along with additive concentration. Taking into account three applied concentrations of additive - molybdenum trioxide (7, 14 and $21 \mathrm{wt}^{\%} \%$ ), a maximum increase in the decomposition temperatures of $30{ }^{\circ} \mathrm{C}$ was observed in the case of sample PES $+21 \% \mathrm{MoO}_{3}$ compared to unmodified polyester. For the maximum mass loss of the studied modified PES, the high concentration of the additive has a significant influence. At molybdenum trioxide content of $21 \mathrm{wt} \%$ found in PES, maximum mass loss decreases from $75 \mathrm{wt}^{\%} \%$ (for unmodified PES) to $46 \mathrm{wt}^{\mathrm{\%}} \%$, which significantly reduces the concentration of the flammable volatile phase and consequently reduces the risk of fire hazard posed by clear polyester material. In case of applying $\mathrm{Sb}_{2} \mathrm{O}_{3}$ as a modifier of PES flammability, changes in thermostability are more apparent. The thermostability of tested polyesters increases at all applied concentrations of antimony trioxide and heating rates. The highest growth in both temperatures is that the beginning of thermal decomposition and maximum mass loss can be observed at $\mathrm{Sb}_{2} \mathrm{O}_{3}$ concentration of $14 \mathrm{wt} \%$ and the heating rate of $10{ }^{\circ} \mathrm{C} / \mathrm{min}$.

The maximum mass loss of the material based on Polimal 1033 APy has been demonstrated at $\mathrm{Sb}_{2} \mathrm{O}_{3}$ content of $21 \mathrm{wt}^{\%} \%(59 \%)$. It should be noticed a significant variation of growth in the temperature of maximum mass loss at applied heating rates. An addition of antipyrenes increases the amount of resulting residues after pyrolysis. The highest amount of ashes after sample combustion can be observed in case of polyester material containing $21 \mathrm{wt} \%$ of $\mathrm{MoO}_{3}$ and the heating rate of $2.5{ }^{\circ} \mathrm{C} / \mathrm{min}$. A comparative analysis of the influence of both tested additives on the studied polyester material, based on the obtained thermogravimetric results, demonstrated antimony trioxide to be a more effective modifier of the flammable properties of the products, based on Polimal 1033 APy rather than molybdenum trioxide increasing its thermostability.

\section{Results and analysis of flammable properties}

Table 2 presents ignition temperatures, the heat of combustion, as well as self-ignition and oxygen indexes obtained during testing the samples of polyester material. The flammable properties of the studied polyester material both modified and unmodified with flame retardants, were analyzed based on the obtained ignition temperatures of thermal decomposi- 
Table 2. Ignition temperature, heat of combustion, self-ignition and oxygen indexes of the studied polyester materials

\begin{tabular}{lcccc}
\hline Material & Ignition tempe-rature $\left({ }^{\circ} \mathrm{C}\right)$ & $\begin{array}{c}\text { Heat of combu-stion } \\
(\mathrm{kJ} / \mathrm{kg})\end{array}$ & $\begin{array}{c}\text { Self-ignition } \\
\text { tempera-ture }\left({ }^{\circ} \mathrm{C}\right)\end{array}$ & Oxygen index $(\%)$ \\
\hline Clear PES & 308 & 26,636 & 380 & 17.2 \\
$\mathrm{PES}+7 \% \mathrm{MoO}_{3}$ & 310 & 23,855 & 391 & 18.9 \\
$\mathrm{PES}+14 \% \mathrm{MoO}_{3}$ & 314 & 22,780 & 410 & 19.0 \\
$\mathrm{PES}+21 \mathrm{MoO}_{3}$ & 320 & 20,726 & 418 & 19.1 \\
$\mathrm{PES}+7 \% \mathrm{Sb}_{2} \mathrm{O}_{3}$ & 309 & 24,420 & 385 & 17.5 \\
$\mathrm{PES}+14 \% \mathrm{Sb}_{2} \mathrm{O}_{3}$ & 310 & 23,165 & 397 & 18.2 \\
$\mathrm{PES}+21 \% \mathrm{Sb}_{2} \mathrm{O}_{3}$ & 315 & 22,168 & 405 & 18.4 \\
\hline
\end{tabular}

tion products, self-ignition temperatures, oxygen indexes and the heat of combustion. Three first values indicating the ability to initiate a combustion reaction listed above were determined applying standard methods using low-energy heat sources. The heat of combustion was determined employing the standard method of material combustion in oxygen. The obtained results of ignition temperature and self-ignition indicate that the impact of both additives on the flammability of the volatile phase, formed as a result of the thermal decomposition of PES, is insignificant taking into account the initiation of combustion that uses the $\mathrm{MoO}_{3}$ modifier.

The maximum difference in the temperature values of ignition regarding unmodified and modified polyester material was $7{ }^{\circ} \mathrm{C}$ at $21 \mathrm{wt} \%$ content of molybdenum oxide in PES and $12{ }^{\circ} \mathrm{C}$ at $21 \mathrm{wt}^{\%} \%$ content of antimony trioxide. In case of self-ignition temperatures of the studied materials, the maximum difference in the values of $38^{\circ} \mathrm{C}$ has been observed for PES including $21 \%$ of $\mathrm{Sb}_{2} \mathrm{O}_{3}$ and $20{ }^{\circ} \mathrm{C}$ for PES with $21 \%$ of $\mathrm{MoO}_{3}$. Most probably, in case of $\mathrm{MoO}_{3}$, it is related to the low volatility of antipyrene, which, as demonstrated in further results, inhibits especially in the condensed phase slightly changing the composition of the volatile phase of the unmodified polyester material. Therefore, the values of both the temperature of the ignition of the volatile products of thermal decomposition and self-ignition temperature, before and after modification are similar. Greater effects of the differentiation of susceptibility for ignition have been demonstrated using $\mathrm{Sb}_{2} \mathrm{O}_{3}$, although antimony trioxide transits into the volatile state much easier, as a result of the thermal decomposition of polyester material, comparing to molybdenum trioxide. The obtained results indicate that the composition of the volatile phase formed during the thermal decomposition of the material modified with $\mathrm{Sb}_{2} \mathrm{O}_{3}$ has a lower ability of flame propagation either in the case of point heat source or heat radiation. The above observations have been also confirmed by the results of measuring the oxygen index (IO) of polyesters. However, mass and heat transfer are different during oxygen index measurements comparing to mass and heat transfer between heat source and material during studies on ignition and self-ignition temperatures. IO values vary insignificantly and thus the studied polyester both unmodified and modified can be still classified as easy to ignite $(\mathrm{IO}<21 \%$ ). Combustion heat values of the studied material with inorganic fillers are lower in comparison with the values for unmodified materials. Along with an increase in the concentrations of the applied oxides, combustion heat values are decreasing. The lowest value has been observed for resin containing $21 \mathrm{wt} \%$ of $\mathrm{Sb}_{2} \mathrm{O}_{3}$. As the effect of adding molybdenum and antimony trioxide and as the antipyrenes of polyester materials, the material made of Polimal 1033 Apy becomes safer in terms of fire hazard and reflects lower fire loading of the buildings in which polyester materials are used as building materials. The above feature allows applying the materials of a lower fire resistance in buildings.

\section{Results and analysis of fire parameters and toxicity}

One of the most important fire parameters and one of the main factors determining the rates of temperature growth and release of toxic products is heat release rate (HRR). The time when HRR reaches the maximum value is crucial; whereas the shorter the time, the greater is the risk for humans and the environment.

With reference to the conducted studies and applied software, the following fire characteristics and flammable properties of the material have been determined:

(1) Heat release rate in $\mathrm{kW} / \mathrm{m}^{2}$ :

- Maximum heat release rate $\mathrm{HRR}_{\max }$ in $\mathrm{kW} / \mathrm{m}^{2}$

- Time for reaching $H R R_{\max }-\mathrm{T}_{\mathrm{HRR} \max }$ in s;

- Mean heat release rate $\mathrm{HRR}_{\text {mean }}$ in $\mathrm{kW} / \mathrm{m}^{2}$;

(2) Mass loss rate MLR in $\mathrm{g} /\left(\mathrm{m}^{2} \mathrm{~s}\right)$ :

- Mean mass loss rate $\mathrm{MLR}_{\text {mean }}$ in $\mathrm{g}\left(\mathrm{m}^{2} \mathrm{~s}\right)$;

(3) Total heat released THR in $\mathrm{MJ} / \mathrm{m}^{2}$;

(4) Effective heat of combustion $\mathrm{HOC}$ in $\mathrm{MJ} / \mathrm{kg}$ :

- Mean effective heat of combustion $\mathrm{HOC}_{\text {mean }}$ in $\mathrm{MJ} / \mathrm{kg}$;

(5) Specific extinction area SEA in $\mathrm{m}^{2} / \mathrm{kg}$ :

- Mean specific extinction area $\mathrm{SEA}_{\text {mean }}$ in $\mathrm{m}^{2} / \mathrm{kg}$

(6) Final sample mass FSM in g;

(7) Time for constant ignition $T_{i g}$ in $s$. 
Table 3. Thermo-kinetic properties of polyester materials containing Polimal 1033 APy unmodified and modified with inorganic oxides under ignition conditions for the external heat flux of $30 \mathrm{~kW} / \mathrm{m}^{2}-$ Part 1

\begin{tabular}{lcccc}
\hline Material & $\mathrm{HRR}_{\text {max }} \mathrm{kW} / \mathrm{m}^{2}$ & $\mathrm{HRR}_{\text {mean }} \mathrm{kW} / \mathrm{m}^{2}$ & $\mathrm{SEA}_{\text {mean }} \mathrm{m}^{2} / \mathrm{kg}$ & $\mathrm{MLR}_{\text {mean }} \mathrm{g} /\left(\mathrm{m}^{2} \cdot \mathrm{s}\right)$ \\
\hline Clear PES & 685 & 340 & 856.1 & 24.2 \\
$\mathrm{PES}+7 \% \mathrm{MoO}_{3}$ & 413 & 244 & 909.9 & 16.6 \\
$\mathrm{PES}+14 \% \mathrm{MoO}_{3}$ & 361 & 204 & 858.6 & 16.3 \\
$\mathrm{PES}+21 \% \mathrm{MoO}_{3}$ & 279 & 164 & 952.6 & 1048.5 \\
$\mathrm{PES}+7 \% \mathrm{Sb}_{2} \mathrm{O}_{3}$ & 402 & 265 & 1068.4 & 17.9 \\
$\mathrm{PES}+14 \% \mathrm{Sb}_{2} \mathrm{O}_{3}$ & 303 & 200 & 1017.5 & 14.4 \\
$\mathrm{PES}+21 \% \mathrm{Sb}_{2} \mathrm{O}_{3}$ & 268 & 166 & & 16.4 \\
\hline
\end{tabular}

The results of conducted studies in the form of selected thermo-physical and thermo-kinetic parameters of studied PES for two different external types of heat flux density -30 and $50 \mathrm{~kW} / \mathrm{m}^{2}$ are shown in Tables 3-6. Figs 2-5 present HRR curves for pure and modified PES with pilot ignition at varying different heat flux density of 30 and $50 \mathrm{~kW} / \mathrm{m}^{2}$.

Based on the conducted cone calorimeter studies, the following observations have been made:

(1) The addition of $7 \mathrm{wt} \%$ of $\mathrm{MoO}_{3}$ and $\mathrm{Sb}_{2} \mathrm{O}_{3}$ to polyester material Polimal 1033 Apy reduces heat release rate for approx. $40-$ $50 \%$ at the analyzed heat flux density (see Tables 3 and 5 and Figs 2-5);

(2) Along with an increase in filler concentration, $\mathrm{HRR}_{\text {max }}$ and $\mathrm{HRR}_{\text {mean }}$ of materials under conditions of ignition are decreasing thus reaching the lowest values of $21 \mathrm{wt} \%$ (see Tables 3 and 5);

(3) Anitmony trioxide more effectively reduces heat release rate from polyester material than molybdenum trioxide. $\mathrm{HRR}_{\max }$ values of the products containing $\mathrm{Sb}_{2} \mathrm{O}_{3}$ are lower for about $20 \%$ compared to the values of the products modified with $\mathrm{MoO}_{3}$ under conditions of ignition and at the studied heat flux density (see Tables 3 and 5);

(4) Independently from $\mathrm{MoO}_{3}$ concentration and heat flux density, HRR curves of

Table 4. Thermo-kinetic properties of polyester materials containing Polimal 1033 APy unmodified and modified with inorganic oxides under ignition conditions for the external heat flux of $30 \mathrm{~kW} / \mathrm{m}^{2}$ - Part 2

\begin{tabular}{lccc}
\hline Material & $\mathrm{T}_{\mathrm{ig}}(s)$ & $\mathrm{T}_{\text {HRRmax }}(s)$ & $\mathrm{THR}\left(\mathrm{MJ} / \mathrm{m}^{2}\right)$ \\
\hline Clear PES & 85 & 475 & 193 \\
$\mathrm{PES}+7 \% \mathrm{MoO}_{3}$ & 85 & 527 & 170 \\
$\mathrm{PES}+14 \% \mathrm{MoO}_{3}$ & 86 & 511 & 161 \\
$\mathrm{PES}+21 \% \mathrm{MoO}_{3}$ & 86 & 613 & 136 \\
$\mathrm{PES}+7 \% \mathrm{Sb}_{2} \mathrm{O}_{3}$ & 95 & 408 & 173 \\
$\mathrm{PES}+14 \% \mathrm{Sb}_{2} \mathrm{O}_{3}$ & 108 & 601 & 155 \\
$\mathrm{PES}+21 \% \mathrm{Sb}_{2} \mathrm{O}_{3}$ & 108 & 275 & 129 \\
\hline
\end{tabular}

PES $+\mathrm{MoO}_{3}$ have two peaks and a specific 'saddle', which indicates the formation of a carbonized layer on the surface of the material. The carbonized layer is a barrier for incoming oxygen and heat, and prevents the spread of the combustion process. The greatest difference in height between two peaks has been observed for PES $+7 \mathrm{wt} \%$ of $\mathrm{MoO}_{3}$. HRR curves of polyester materials containing $\mathrm{Sb}_{2} \mathrm{O}_{3}$ are characterized by more stable HRR values compared to PES with $\mathrm{MoO}_{3}$ in the whole combustion range. The above indicates a lack of the carbonized layer or the formation of a very small layer (see Figs 2-5);

(5) Along with an increase in the concentration of both flame retardants, heat release rate from modified PES is decreasing (see Tables 3 and 5 and Figs 2-5);

(6) Maximum HRR values and mean HRR values of unmodified and modified polyester materials based on Polimal 1033 Apy at the applied heat flux of $30 \mathrm{~kW} / \mathrm{m}^{2}$ are lower for about $40-50 \%$ compared to the values observed at the heat flux of $50 \mathrm{~kW} / \mathrm{m}^{2}$ (see Tables 3 and 5);

(7) Maximum heat release rates for unmodified and modified PES for applied heat flux density depend on the method of initiating the combustion process. The combustion theory distinguishes three types of combustion initiation: ignition, self-ignition and spontaneous combustion. Due to the fact that unmodified and modified polyester material does not undergo spontaneous combustion, the studies used two other types determining fire occurrence. Under conditions of selfignition, $H_{R R} R_{\max }$ values of the studied materials are lower comparing to the corresponding materials under conditions of the ignition of pyrolytic products. The difference in $H_{R R} R_{\text {max }}$ between materials arising from various types of the combustion initiation process is $14 \%$ at $30 \mathrm{~kW} / \mathrm{m}^{2}$ and $15-20 \%$ at $50 \mathrm{~kW} / \mathrm{m}^{2}$; 
Table 5. Thermokinetic properties of polyester materials containing Polimal 1033 APy unmodified and modified with inorganic oxides under ignition conditions for the external heat flux of $50 \mathrm{~kW} / \mathrm{m}^{2}-$ Part 1

\begin{tabular}{lcccc}
\hline Material & $\mathrm{HRR}_{\text {max }} \mathrm{kW} / \mathrm{m}^{2}$ & $\mathrm{HRR}_{\text {mean }} \mathrm{kW} / \mathrm{m}^{2}$ & $\mathrm{SEA}_{\text {mean }} \mathrm{m}^{2} / \mathrm{kg}$ & $\mathrm{MLR}_{\text {mean }} \mathrm{g} /\left(\mathrm{m}^{2} \mathrm{~s}\right)$ \\
\hline Clear PES & 1011 & 448 & 826.5 & 31.3 \\
$\mathrm{PES}+7 \% \mathrm{MoO}_{3}$ & 575 & 355 & 1090.4 & 22.0 \\
$\mathrm{PES}+14 \% \mathrm{MoO}_{3}$ & 564 & 344 & 1060.6 & 20.8 \\
$\mathrm{PES}+21 \% \mathrm{MoO}_{3}$ & 531 & 309 & 1118.7 & 18.5 \\
$\mathrm{PES}+7 \% \mathrm{Sb}_{2} \mathrm{O}_{3}$ & 572 & 351 & 1121.0 & 24.4 \\
$\mathrm{PES}+14 \% \mathrm{Sb}_{2} \mathrm{O}_{3}$ & 458 & 302 & 1160.1 & 20.6 \\
$\mathrm{PES}+21 \% \mathrm{Sb}_{2} \mathrm{O}_{3}$ & 427 & 266 & 1099.3 & 19.2 \\
\hline
\end{tabular}

(8) Time for the ignition and self-ignition of polyester materials modified with inorganic oxides are longer comparing to corresponding time for unmodified polyester. Together with an increase in the filler content of the material, the initiation of the reaction in the material becomes more difficult, while time for ignition and self-ignition becomes longer. Polyester material containing $\mathrm{Sb}_{2} \mathrm{O}_{3}$ is characterized by longer time for ignition and selfignition comparing to time for PES with $\mathrm{MoO}_{3}$. The greatest difference in time for ignition and self-ignition can be noticed in the results obtained at the heat flux of $30 \mathrm{~kW} / \mathrm{m}^{2}$ and conditions under the ignition of pyrolytic products. Molybdenum trioxide used as an additive for PES comparing to unmodified polyester, slightly extends time for ignition and self-ignition. Only in case of the material containing $21 \mathrm{wt} \%$ of $\mathrm{MoO}_{3}$ under conditions of self-ignition and heat flux density of $30 \mathrm{~kW} / \mathrm{m}^{2}$, time for sample self-ignition is longer for $17 \%$ than time for the self-ignition of the unmodified material. Time for the ignition and self-ignition of the studied materials depends not only on the type and concentrations of fillers, but also on the heat release rate and type of combustion process initiation. At a lower heat flux of $30 \mathrm{~kW} / \mathrm{m}^{2}$, time for the ignition or selfignition of the studied PESs is longer than at the flux of $50 \mathrm{~kW} / \mathrm{m}^{2}$ (see Tables 4 and 6);

Table 6. Thermokinetic properties of unmodified and modified polyester materials at the heat flux density of $50 \mathrm{~kW} / \mathrm{m}^{2}$ on piloted ignition - Part 2

\begin{tabular}{lccc}
\hline Material & $\mathrm{T}_{\text {ig }}(s)$ & $\mathrm{T}_{\text {HRRmax }}(s)$ & THR $\left(\mathrm{MJ} / \mathrm{m}^{2}\right)$ \\
\hline Clear PES & 40 & 343 & 198 \\
$\mathrm{PES}+7 \% \mathrm{MoO}_{3}$ & 40 & 383 & 204 \\
$\mathrm{PES}+14 \% \mathrm{MoO}_{3}$ & 40 & 99 & 197 \\
$\mathrm{PES}+21 \% \mathrm{MoO}_{3}$ & 40 & 98 & 189 \\
$\mathrm{PES}+7 \% \mathrm{Sb}_{2} \mathrm{O}_{3}$ & 40 & 224 & 178 \\
$\mathrm{PES}+14 \% \mathrm{Sb}_{2} \mathrm{O}_{3}$ & 40 & 389 & 164 \\
PES $+21 \% \mathrm{Sb}_{2} \mathrm{O}_{3}$ & 46 & 381 & 153 \\
\hline
\end{tabular}

(9) The application of the auxiliary ignition source (spark igniter) speeds up the ignition of a volatile mixture of the products of thermal decomposition with the air. At the heat flux of $30 \mathrm{~kW} / \mathrm{m}^{2}$ and under conditions of self-ignition, time for initiating the combustion process of materials is the longest;

(10) The influence of polyester material modified with inorganic oxides $\left(\mathrm{MoO}_{3}\right.$ and $\left.\mathrm{Sb}_{2} \mathrm{O}_{3}\right)$ can be also noticed, when analyzing the values of total heat released (THR) and mean effective heat of combustion (HOC), taking into account the mass loss rate of polyesters during combustion. Together with the increasing percentage content of oxides in the studied materials, the values of THR and HOC are decreasing; the impact of $\mathrm{MoO}_{3}$ and $\mathrm{Sb}_{2} \mathrm{O}_{3}$ is similar (see Tables 4 and 6);

(11) The mean mass loss rates $\left(M_{L} R_{\text {mean }}\right)$ of the studied polyester materials under ignition and self-ignition conditions decrease along with an increase in the concentrations of the applied fillers. The highest value of $M R_{\text {mean }}$ has been observed for unmodified PES. The thermal decomposition of crosslinked Polimal 1033 Apy including $\mathrm{Sb}_{2} \mathrm{O}_{3}$ proceeds faster than with $\mathrm{MoO}_{3}$; it is indicated by higher values of $M R_{\text {mean }}$ for materials containing $\mathrm{Sb}_{2} \mathrm{O}_{3}$ in the studied

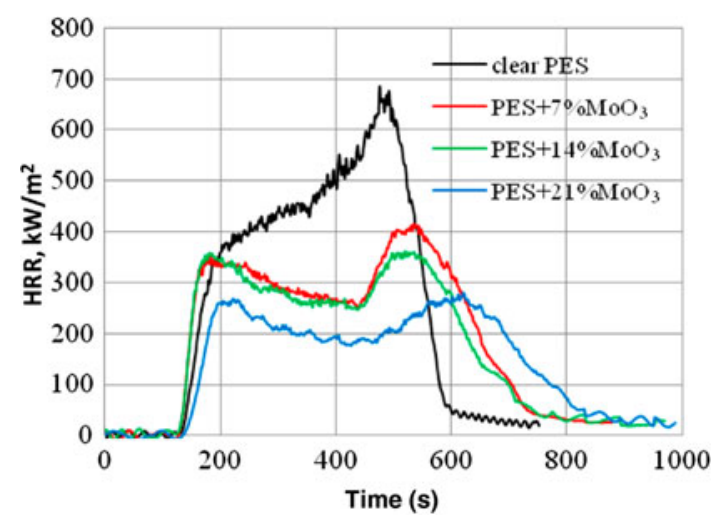

Fig. 2. Heat release rate for polyester material unmodified and modified with $\mathrm{MoO}_{3}$ at the heat flux density of $30 \mathrm{~kW} / \mathrm{m}^{2}$ on piloted ignition 


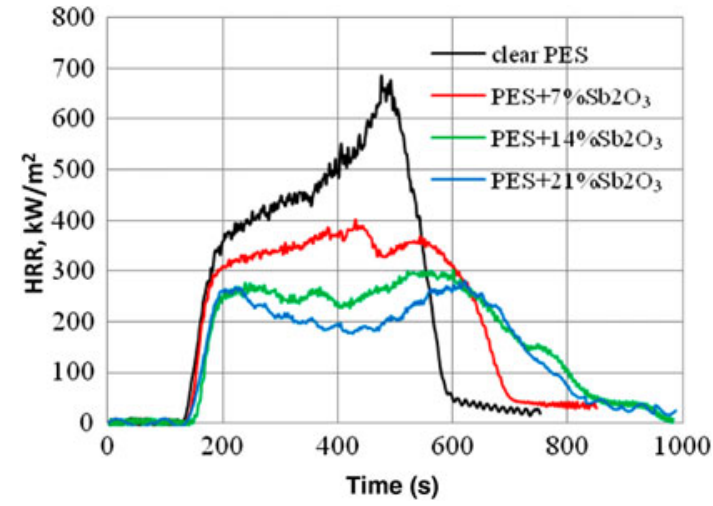

Fig. 3. Heat release rate for polyester material unmodified and modified with $\mathrm{Sb}_{2} \mathrm{O}_{3}$ at the heat flux density of $30 \mathrm{~kW} / \mathrm{m}^{2}$ on piloted ignition

heat fluxes independently from the combustion initiation method. Considering the initial and final mass of the studied samples, it should be emphasized that, in most cases, residual mass after pyrolysis is larger for materials containing $\mathrm{MoO}_{3}$. Investigated materials containing $\mathrm{Sb}_{2} \mathrm{O}_{3}$ under the influence of incident heat flux mostly demonstrate lower (comparing to the one containing $\mathrm{MoO}_{3}$ ) ash content after combustion (see Tables 3 and 5);

(12) Flame retardants $\mathrm{Sb}_{2} \mathrm{O}_{3}$ and $\mathrm{MoO}_{3}$ added to polyester resin increase the mean coefficient of the specific extinction area (SEA) of the material. The studied polyesters containing $\mathrm{MoO}_{3}$ at the given heat flux and under ignition conditions demonstrate a lower SEA value of approx. $15 \%$ compared to the materials containing $\mathrm{Sb}_{2} \mathrm{O}_{3}$ (see Tables 3 and 5).

Studies on polyester resins have indicated that the additives do not have a significant influence on changes in toxicity. Toxicological profiles of concentrations for the studied substances with regards to

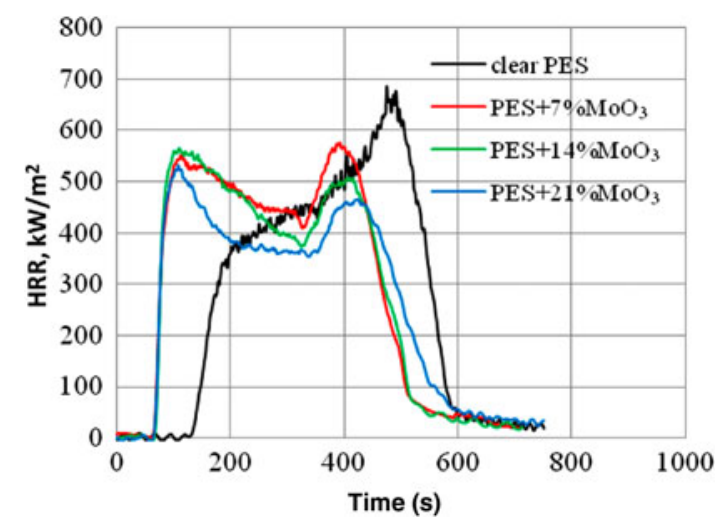

Fig. 4. Heat release rate for polyester material unmodified and modified with $\mathrm{MoO}_{3}$ at the heat flux density of $50 \mathrm{~kW} / \mathrm{m}^{2}$ on piloted ignition

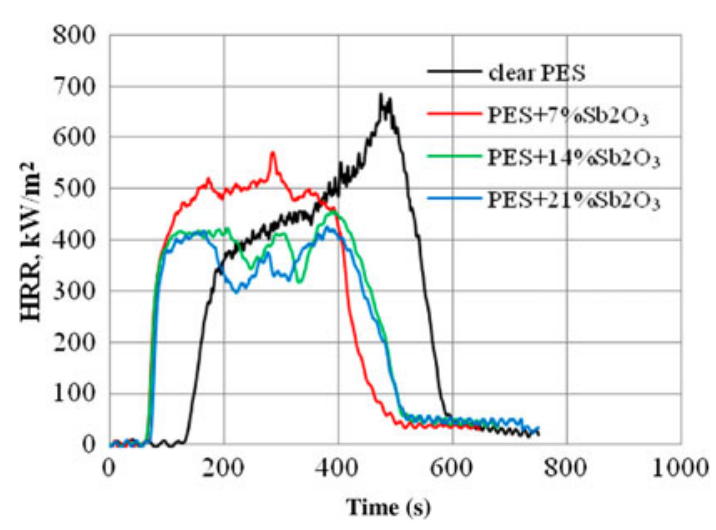

Fig. 5. Heat release rate for polyester material unmodified and modified with $\mathrm{Sb}_{2} \mathrm{O}_{3}$ at the heat flux density of $50 \mathrm{~kW} / \mathrm{m}^{2}$ on piloted ignition

temperature allows noticing that along with temperature growth $\mathrm{CO}$ concentration drops and $\mathrm{CO}_{2}$ increases. It has been shown that adding the antimony trioxide of $7 \mathrm{wt} \%$ results in a slight increase in toxicity, whereas in case of the sample consisting of $14 \mathrm{wt} \%$, toxicity drops reaching the best result from all studied materials.

The main conclusion resulting from the analysis of the obtained results is that all studied materials were classified as moderately toxic thus being at the lowest safest limit according to PN-88/B-02855 (1988). The received results are presented in Tables 7-12.

Definitions of toxic indicators:

- toxic indicator $W_{L \mathrm{C} 50}\left[\mathrm{~g} / \mathrm{m}^{3}\right]$ - the weight of the given material, the decomposition or burning of which under testing conditions generated toxic threshold concentration of the given decomposition or burning product:

$$
W_{L C 50}=\frac{L C_{50}}{E},
$$

where: $L C_{50}\left[\mathrm{~g} / \mathrm{m}^{3}\right]$ - threshold concentration of the given thermal decomposition product that causes the death of $50 \%$ of the population at an exposition of 30 minutes; $E$ - specific emission $[\mathrm{g} / \mathrm{g}]$ (mean arithmetical value of the specific emission value in view of the results of at least two tests);

Table 7. Toxicometric indicators of unmodified polyester material

\begin{tabular}{|c|c|c|c|c|}
\hline \multirow{2}{*}{$\begin{array}{l}\text { Decomposition } \\
\text { temperature }\left({ }^{\circ} \mathrm{C}\right)\end{array}$} & \multicolumn{2}{|c|}{$W_{L C 50}\left(\mathrm{~g} / \mathrm{m}^{3}\right)$} & \multirow{2}{*}{$\begin{array}{l}W_{L C 50 M} \\
\left(\mathrm{~g} / \mathrm{m}^{3}\right)\end{array}$} & \multirow{2}{*}{$\begin{array}{c}W_{L C 50 S M} \\
\left(\mathrm{~g} / \mathrm{m}^{3}\right)\end{array}$} \\
\hline & $\mathrm{CO}$ & $\mathrm{CO}_{2}$ & & \\
\hline 450 & 167.6 & 2231.2 & 155.9 & 93.3 \\
\hline 550 & 92.4 & 1419.9 & 86.7 & \\
\hline 750 & 88.6 & 64.0 & 37.1 & \\
\hline
\end{tabular}


Table 8. Toxicometric indicators of modified polyester material $+7 \mathrm{wt} \% \mathrm{Sb}_{2} \mathrm{O}_{3}$

\begin{tabular}{|c|c|c|c|c|}
\hline \multirow{2}{*}{$\begin{array}{l}\text { Decomposition } \\
\text { temperature }\left({ }^{\circ} \mathrm{C}\right)\end{array}$} & \multicolumn{2}{|c|}{$W_{L C 50}\left(\mathrm{~g} / \mathrm{m}^{3}\right)$} & \multirow{2}{*}{$\begin{array}{c}W_{L C 50 M} \\
\left(\mathrm{~g} / \mathrm{m}^{3}\right)\end{array}$} & \multirow{2}{*}{$\begin{array}{c}W_{L C 50 S M} \\
\left(\mathrm{~g} / \mathrm{m}^{3}\right)\end{array}$} \\
\hline & $\mathrm{CO}$ & $\mathrm{CO}_{2}$ & & \\
\hline 450 & 221.2 & 1610.5 & 194.5 & 86.9 \\
\hline 550 & 40.9 & 448.9 & 37.5 & \\
\hline 750 & 49.8 & 67.4 & 28.6 & \\
\hline
\end{tabular}

- toxic indicator $W_{L C 50 M}\left[\mathrm{~g} / \mathrm{m}^{3}\right]$ - the resultant of indicator $W_{L C 50}$ considering particular decomposition and burning products for the given temperature, delimited pursuant to the formula:

$$
\frac{1}{W_{L C 50 M}}=\sum^{n} \frac{1}{W_{L C 50}}
$$

where: $n$ - the number of determined products; - toxic indicator $W_{L C 50 S M}\left[\mathrm{~g} / \mathrm{m}^{3}\right]$ - the mean arithmetical value of indicators $\mathrm{W}_{\mathrm{LC} 50 \mathrm{M}}$ from particular temperature ranges $\left(450{ }^{\circ} \mathrm{C}\right.$, $\left.550{ }^{\circ} \mathrm{C}, 750^{\circ} \mathrm{C}\right) . W_{L C 50 S M}$ indicators are used for classifying materials:

$$
W_{L C 50 S M}=\frac{W_{L C 50 M .450}+W_{L C 50 M .550}+W_{L C 50 M .750}}{3} .
$$

Chemical decomposition and burning products according to PN-88/B-02855 (1988) are classified taking into account appropriate groups presented in Table 13.

\section{Summary and general conclusions}

The paper focuses on the results of small-scale studies considering the evaluation of the flammability of new polyester materials based on Polimal 1033 APy resin, in which special flame retardants, such as molybdenum and antimony trioxides found in different content (7 wt $\%, 14 \mathrm{wt}^{\mathrm{t}} \%$ and $21 \mathrm{wt} \%$ ) are used. The obtained results have been compared with data received from pure resin without any additives.

With reference to the analysis of the obtained results, the following conclusions have been formulated.

Table 9. Toxicometric indicators of modified polyester

\begin{tabular}{|c|c|c|c|c|}
\hline \multirow{2}{*}{$\begin{array}{l}\text { Decomposition } \\
\text { temperature }\left({ }^{\circ} \mathrm{C}\right)\end{array}$} & \multicolumn{2}{|c|}{$W_{L C 50}\left(\mathrm{~g} / \mathrm{m}^{3}\right)$} & \multirow{2}{*}{$\begin{array}{c}W_{L C 50 M} \\
\left(\mathrm{~g} / \mathrm{m}^{3}\right)\end{array}$} & \multirow{2}{*}{$\begin{array}{c}W_{L C 50 S M} \\
\left(\mathrm{~g} / \mathrm{m}^{3}\right)\end{array}$} \\
\hline & $\mathrm{CO}$ & $\mathrm{CO}_{2}$ & & \\
\hline 450 & 448.6 & 2790.3 & 371.5 & 139.6 \\
\hline 550 & 35.7 & 535.6 & 33.5 & \\
\hline 750 & 18.3 & 56.7 & 13.9 & \\
\hline
\end{tabular}
material $+14 \mathrm{wt}^{2} \% \mathrm{Sb}_{2} \mathrm{O}_{3}$
Table 10. Toxicometric indicators of modified polyester material $+7 \mathrm{wt}^{\%} \mathrm{MoO}_{3}$

\begin{tabular}{lrrrr}
\hline $\begin{array}{c}\text { Decomposition } \\
\text { temperature }\left({ }^{\circ} \mathrm{C}\right)\end{array}$ & \multicolumn{2}{c}{$W_{L C 50}\left(\mathrm{~g} / \mathrm{m}^{3}\right)$} & $W_{L C 50 M}$ & $\begin{array}{c}W_{L C 50 S M} \\
\left(\mathrm{~g} / \mathrm{m}^{3}\right)\end{array}$ \\
\cline { 2 - 3 }$\left(\mathrm{g} / \mathrm{m}^{3}\right)$ & 127.0 & 1797.5 & 118.6 & 56.3 \\
450 & 38.1 & 544.1 & 35.6 & \\
750 & 20.5 & 50.7 & 14.6 & \\
\hline
\end{tabular}

Molybdenum and antimony trioxides introduced to polyester resin change the flammable properties and fire characteristic of the studied polyester material. Together with the increasing content of inorganic oxides, the modified materials based on Polimal 1033 APy become safer from the point of view of fire hazard. It is indicated by higher values of heat combustion, lower heat release rates of the modified materials under considered heat flux and in consequence of a lower fire load of the buildings, where structural elements are made of non-saturated polyester resins. Higher values of the ignition temperature of volatile products and self-ignition and time for ignition or self-ignition confirm the above conclusion, since polyester materials containing flame retardants $\mathrm{MoO}_{3}$ and $\mathrm{Sb}_{2} \mathrm{O}_{3}$ inhibit the initiation of the combustion reaction, and thus inhibit fire development at its initial phase. An inhibitive impact of antimony trioxide on self-ignition and ignition temperatures and time for the self-ignition and ignition of PES is greater comparing the above temperatures and time for the material containing molybdenum trioxide. The effectiveness of $\mathrm{Sb}_{2} \mathrm{O}_{3}$ as antipyrene for polyester materials is the most evident when $\mathrm{Sb}_{2} \mathrm{O}_{3}$ concentration is $21 \mathrm{wt} \%$. Antimony trioxide has a greater influence on the thermostability of the investigated material based on Polimal 1033 APy compared to molybdenum trioxide in all cases of heat flux density and all additive concentrations. There is a significant diversification of temperature growth in maximum mass loss in light of the studied heating rates, which indicates that the thermal decomposition of the studied polyester materials is a function of their composition and heating rate. The temperatures of the initial thermal decomposition of polyesters modified with oxides are higher compared to unmodified materials. The addition of inorganic fillers to PES

Table 11. Toxicometric indicators of modified polyester

\begin{tabular}{|c|c|c|c|c|}
\hline \multirow{2}{*}{$\begin{array}{l}\text { Decomposition } \\
\text { temperature }\left({ }^{\circ} \mathrm{C}\right)\end{array}$} & \multicolumn{2}{|c|}{$W_{L C 50}\left(\mathrm{~g} / \mathrm{m}^{3}\right)$} & \multirow{2}{*}{$\begin{array}{c}W_{L C 50 M} \\
\left(\mathrm{~g} / \mathrm{m}^{3}\right)\end{array}$} & \multirow{2}{*}{$\begin{array}{c}W_{L C 50 S M} \\
\left(\mathrm{~g} / \mathrm{m}^{3}\right)\end{array}$} \\
\hline & $\mathrm{CO}$ & $\mathrm{CO}_{2}$ & & \\
\hline 450 & 158.4 & 1523.6 & 143.5 & 68.9 \\
\hline 550 & 44.1 & 1025.6 & 42.2 & \\
\hline 750 & 28.0 & 81.3 & 20.8 & \\
\hline
\end{tabular}
material $+14 \mathrm{wt}^{2} \% \mathrm{MoO}_{3}$ 
Table 12. Toxicity classification of the thermal decomposition products and combustion of unmodified and modified polyester materials

\begin{tabular}{lcc}
\hline Material & $W_{L C 50 S M}\left(\mathrm{~g} / \mathrm{m}^{3}\right)$ & Toxicity class \\
\hline Clear PES & 93.3 & Moderately toxic \\
PES $+7 \% \mathrm{Sb}_{2} \mathrm{O}_{3}$ & 86.9 & \\
$\mathrm{PES}+14 \% \mathrm{Sb}_{2} \mathrm{O}_{3}$ & 139.6 & \\
$\mathrm{PES}+7 \% \mathrm{MoO}_{3}$ & 56.3 & \\
PES $+14 \% \mathrm{MoO}_{3}$ & 68.9 & \\
\hline
\end{tabular}

results in a growth in the temperatures of maximum mass loss during thermal decomposition and simultaneously in the increased amount of residues after pyrolysis. The mass of ashes obtained from polyester samples containing $\mathrm{MoO}_{3}$ in view of the studied heat flux density is higher compared to unmodified materials and those containing $\mathrm{Sb}_{2} \mathrm{O}_{3}$ in considered concentrations.

The inhibitory effect of $\mathrm{Sb}_{2} \mathrm{O}_{3}$ on the studied material is related to both the condensed phase and the volatile phase. It is demonstrated by longer time for the ignition and self-ignition of the material consisting of Polimal 1033 Apy containing $\mathrm{Sb}_{2} \mathrm{O}_{3}$, compared to the material composed of $\mathrm{MoO}_{3}$ clear PES at the heat flux density of 30 and $50 \mathrm{~kW} / \mathrm{m}^{2}$. Antimony trioxide included in PES during the heating process shows greater tendency to transit into the volatile phase than molybdenum trioxide and indicates inhibiting time for ignition. Molybdenum trioxide applied in PES only slightly influences changes in time for the ignition or self-ignition of modified materials under studied conditions.

Toxicity studies resulting in the determination of toxicometric indicators have demonstrated that both unmodified and modified PES are moderately toxic. Therefore, the influence of additives on the toxicity of the studied materials is insignificant. However, it should be emphasized that the lowest toxicity among all introduced samples $\left(W_{L C 50 S M}=139.6 \mathrm{~g} / \mathrm{m}^{3}\right)$ was observed in PES containing $14 \mathrm{wt}^{\%} \%$ of antimony trioxide.

The applied flame retardants even at the concentration of $7 \mathrm{wt}^{\%} \%$ cause a significant reduction in heat release rate for approx. $40 \%$ (from $700 \mathrm{~kW} / \mathrm{m}^{2}$ to $400 \mathrm{~kW} / 2$ ). A further increase in the content of additives, though to a lesser degree of approx. $30 \%$, further decreases HRR values. The lowest $H_{R} R_{\text {max }}$ values of about $300 \mathrm{~kW} / \mathrm{m}^{2}$ at the heat flux of $30 \mathrm{~kW} / \mathrm{m}^{2}$

Table 13. Toxic properties of decomposition and burning products of materials

\begin{tabular}{ll}
\hline$W_{L C 50 S M}$ & $\begin{array}{l}\text { Toxic properties of decomposition and } \\
\text { burning products of materials }\end{array}$ \\
\hline$\leq 15$ & Very toxic \\
$>15, \leq 40$ & Toxic \\
$>40$ & Moderately toxic \\
\hline
\end{tabular}

and $450 \mathrm{~kW} / \mathrm{m}^{2}$ and the radiation source of $50 \mathrm{~kW} / \mathrm{m}^{2}$ were obtained in the concentration of $21 \mathrm{wt} \%$.

In the range of $200-600 \mathrm{~s}$ at $30 \mathrm{~kW} / \mathrm{m}^{2}$ and 100 $400 \mathrm{~s}$ at $50 \mathrm{~kW} / \mathrm{m}^{2}$, with the exception of the sample containing $7 \mathrm{wt}^{\%} \%$ of $\mathrm{Sb}_{2} \mathrm{O}_{3}$, a visible local reduction in heat release rate in case of all modified samples (from 50 to $150 \mathrm{~kW} / \mathrm{m}^{2}$ ) can be observed and indicates the formation of the carbonated zone on the surface, which is a barrier to incoming oxygen and heat, thus reducing flame propagation.

During combustion initiated by spark ignition in case of the sample with no additives, heat release rate constantly increases very rapidly in the first phase and slows down up to the maximum value within next 200 s. In case of the samples containing additives, after approximately $200 \mathrm{~s}$ for $30 \mathrm{~kW} / \mathrm{m}^{2}$ and after $100 \mathrm{~s}$ for $50 \mathrm{~kW} / \mathrm{m}^{2}$ and following a rapid increase in HRR, the value stabilizes approximately at the level of $250 \mathrm{~kW} / \mathrm{m}^{2}$ at the heat flux of $30 \mathrm{~kW} / \mathrm{m}^{2}$ or at the level of $300-400 \mathrm{~kW} / \mathrm{m}^{2}$ at the heat flux of $50 \mathrm{~kW} / \mathrm{m}^{2}$, and, in most cases, forms a specific 'saddle'.

\section{References}

ASTM, D. 1929-77. Standard test method for determining ignition temperature of plastics. West Conshohocken, PA, USA: American Society for Testing and Materials (ASTM). 10 p.

Carosio, F.; Alongi, J.; Malucelli, G. 2012. Layer by layer ammonium polyphosphate-based coatings for flame retardancy of polyester-cotton blends, Carbohydrate Polymers 88(4): 1460-1469. http://dx.doi.org/10.1016/j.carbpol.2012.02.049

Fukushima, K.; Murariu, M.; Camino, G.; Dubois, P. 2010. Effect of expanded graphite/layered-silicate clay on thermal, mechanical and fire retardant properties of poly(lactic acid), Polymer Degradation and Stability 95(6): 1063-1076.

http://dx.doi.org/10.1016/j.polymdegradstab.2010.02.029

Gałaj, J.; Półka, M.; Wnęk, W. 2012. Influence of additive flame retardants on some fire properties of epoxy materials, Przemysl Chemiczny 91(7): 1000-1006.

ISO 5660-1:2002. 2002. Reaction-to-fire tests - Heat release, smoke production and mass loss rate - Part 1: Heat release rate (cone calorimeter method). Geneva, Switzerland: International Organization for Standardization. 39 p.

Jankowska, G.; Przygocki, W.; Włochowicz, A. 2007. Palność polimerów $i$ materiałów polimerowych [Flammability of polymers and polymeric materials]. Warsaw: WNT. $344 \mathrm{p}$.

Kandare, E.; Kandola, B. K.; Price, D.; Nazaré, S.; Horrocks, R. A. 2008. Study of thermal decomposition of flame-retarded unsaturated polyester resins by thermogravimetric analysis and Py-GC/MS, Polymer Degradation and Stability 93(11): 1996-2006. http://dx.doi.org/10.1016/j.polymdegradstab.2008.03.032

Kiliaris, P.; Papaspyrides, C. D. 2010. Polymer/layered silicate (clay) nanocomposities: an overview of flame retardancy, Progress in Polymer Science 35(7): 902-958. http://dx.doi.org/10.1016/j.progpolymsci.2010.03.001 
Konecki, M.; Półka, M. 2005. Wykorzystanie metody kalorymetru stozkowego do szacowania zasieggu widzialnosci w dymie powstałym w czasie spalania materiałów poliestrowych [The use of cone calorimeter method to estimate the range of visibility in smoke, formed during the combustion of materials of polyester], in The 5th International Conference on Fire Safety, 14-16 July, 2005, Warsaw, Poland.

Konecki, M.; Półka, M. 2006. Analiza zasięgu widzialności $\mathrm{w}$ dymie powstalym $\mathrm{w}$ czasie spalania materiałów poliestrowych [Analysis of visibility range in a smoke produced during combustion of polyester materials], Polimery 51(4): 46-53.

Konecki, M.; Półka, M. 2009a. Simple fire model for comparative studies of critical conditions during combustion of chosen polymer materials, Journal of Civil Engineering and Management 15(3): 247-257. http://dx.doi.org/10.3846/1392-3730.2009.15.247-257

Konecki, M.; Półka, M. 2009b. Analiza rozprzestrzeniania się ciepła i dymu w czasie spalania wybranych materiałów poliestrowych [Analysis of heat and smoke spreading during combustion of chosen polyester material], Przemyst Chemiczny 88(2): 4-14.

Laoutid, F.; Bonnaud, L.; Alexandre, M.; Lopez-Cuesta, J.-M.; Dubois, P. 2009. New prospects in flame retardant polymer materials: from fundamentals to nanocomposities, Materials Science and Engineering: R: Reports 63(3): 100-125.

http://dx.doi.org/10.1016/j.mser.2008.09.002

Li, N.; Xia, Y.; Mao, Z.; Wang, L.; Guan, Y.; Zheng, A. 2012. Influence of antimony oxide on flammability of polypropylene/intumescent flame retardant system, Polymer Degradation and Stability 97(9): 1737-1744. http://dx.doi.org/10.1016/j.polymdegradstab.2012.06.011

Pan, L. L.; Li, G. Y.; Su, Y. C.; Lian, J. S. 2012. Fire retardant mechanism analysis between ammonium polyphosphate and triphenyl phosphate in unsaturated polyester resin, Polymer Degradation and Stability 97(9): 1801-1806.

http://dx.doi.org/10.1016/j.polymdegradstab.2012.06.002

Pereira, C. M. C.; Herrero, M.; Labajos, F. M.; Marques, A. T.; Rives, V. 2009. Preparation and properties of new flame retardant unsaturated polyester nanocomposites based on layered double hydroxides, Polymer Degradation and Stability 94(6): 939-946.

http://dx.doi.org/10.1016/j.polymdegradstab.2009.03.009

PN-69/C-89022. 1969. Tworzywa sztuczne. Oznaczanie temperatury zapalenia [Plastics. Determination of ignition temperature]. Warsaw: Polish Committee for Standardization. 2 p.

PN-76/C-89056. 1976. Tworzywa sztuczne. Oznaczanie zawartosci koagulatu $w$ wodnych dyspersjach polimerów $i$ kopolimerów [Plastics. Determination of the coagulum in the aqueous dispersions of polymers and copolymers]. Polish Committee for Standardization. $4 \mathrm{p}$.

PN-81/G-04513. 1981. Paliwa stałe - Oznaczanie ciepla spalania $i$ obliczanie wartosci opałowej [Solid fuels Determination of the heat of combustion and calculation of net calorific value]. Warsaw: Polish Committee for Standardization. $11 \mathrm{p}$.
PN-88/B-02855. 1988. Ochrona przeciwpozarowa budynkówMetoda badania wydzielania toksycznych produktów rozkładu $i$ spalania materiałów [Fire protection of buildings - test method for release of toxic products of decomposition and combustion of materials]. Warsaw: Polish Committee for Standardization. 7 p.

Pofit Szczepańska, M.; Półka, M. 2002a. Analityczny opis kształtu krzywych kinetyki generacji ciepła materiałów poliestrowych oraz wskaźników spalania badanych poliestrów [Analytical description of the curves obtaining during investigation of kinetics of heat generation during combustion of polyester materials and burning indexes], Archiwum Spalania 2(1): 33-41.

Pofit Szczepańska, M.; Półka, M. 2002b. Mechanizm oddziaływania ogniochronnego dodatków nieorganicznych na palność materiałów poliestrowych otrzymanych na bazie żywicy Polimal 1033APy [Mechanism of influence of flame retardant inorganic additives on flammability of polyester materials basing on the resin Polimal 1033APy], Archiwum Spalania 2(1): 22-32.

Pofit Szczepańska, M.; Półka, M. 2003. Analiza toksyczności produktów rozkladu termicznego i spalania modyfikowanych i nie modyfikowanych materiałów poliestrowych [Analysis of toxicity of thermal decomposition and combustion products of modified and unmodified polyester materials], Zeszyty Naukowe SGSP 29: 45-58.

Półka, M. 2001. Wpływ dodatków nieorganicznych na palnosć modyfikowanych materiałów poliestrowych [Influence of inorganic additives on flammability of modified polyester materials]. Doctoral thesis. Technical University in Szczecin, Department of Technology and Chemical Engineering, Poland.

Seetapan, N.; Limparyoon, N.; Kiatkamjornwong, S. 2011. Effect of fire retardant on flammability of acrylamide and 2-acrylamido-2-methylpropane sodium sulfonate copolymer composites, Polymer Degradation and Stability 96(10): 1927-1933.

http://dx.doi.org/10.1016/j.polymdegradstab.2011.06.014

Tang, Z.; Li, Y.; Zhang, Y. J.; Jiang, P. 2012. Oligomeric siloxane containing triphenylphosphonium phosphate as a novel flame retardant for polycarbonate, Polymer Degradation and Stability 97(4): 638-644.

http://dx.doi.org/10.1016/j.polymdegradstab.2012.01.002

Tibiletti, L.; Longuet, C.; Ferry, L.; Coutelen, P.; Mas, A.; Robin, J.-J.; Lopez-Cuesta, J.-M. 2011. Thermal degradation and fire behaviour of unsaturated polyesters filled with metallic oxides, Polymer Degradation and Stability 96(1): 67-75.

http://dx.doi.org/10.1016/j.polymdegradstab.2010.10.015

Wei, L.-L.; Wang, D.-Y; Chen, H.-B; Chen, L.; Wang, X.-L.; Wang, Y.-Z. 2011. Effect of phosphorus-containing flame retardant on the thermal properties and ease of ignition of poly(lactic acid), Polymer Degradation and Stability 96(9): 1557-1561. http://dx.doi.org/10.1016/j.polymdegradstab.2011.05.018

Wilkie, C. A.; Morgan, A. B. 2010. Fire retardancy of polymeric materials. CRC Press, Boca Raton, USA: Taylor \& Francis Group. 928 p. 
Marzena PÓŁKA. Associate Professor, Dr Habil, the Dean at the Department of Fire Safety Engineering, The Main School of Fire Service, Warsaw. Publications: the author of over 50 scientific publications. Research interests: combustion of polymer materials, cone calorimeter methods, thermal properties of materials, dust explosion.

Jerzy GAŁAJ. PhD, the Head of Hydromechanics Division at the Department of Fire Safety Engineering, the Main School of Fire Service, Warsaw. Publications: the author of over 50 scientific publications. Research interests: fire modelling, modelling of extinguishing systems, fire safety engineering, full-scale fire tests, flow characteristics of firefighting systems.

Zbignev KARPOVIČ. PhD at the Department of Labour Safety and Fire Protection, Vilnius Gediminas Technical University (VGTU). Publications: 8 scientific publications. Research interests: protective features of flame retardants, fire safety of impregnated timber. 